\title{
David Hiley
}

\section{Recent research on the origins of Western chant}

Some years ago, Mary Berry contributed to this journal a history of plainchant on record (EM Apr 1979), which outlined some of the various ways in which chant has been performed The subject of the present essay is to some extent complementary work on the origins of chant and its development as a liturgical and musical repertory, where it came from and how it reached the differing states in which we know it Inevitably such a survey will be somewhat distorted by my personal view of affairs, and by the superficiality and compression necessary for reasons of space My hope is that readers will end up with at least an impression of the problems with which chant scholars are wrestling, be stimulated to investigate the specialist literature for themselves, and seek out and sing some of the music discussed

One impulse behind research into the early history of plainchant has been the desire to restore the music available in modern service books to something like its common medieval form, based on the earliest surviving music manuscripts of the late 9th and 10th centuries The result is naturally a compromise: the various forms of the Roman liturgy in the twentieth century are not exactly those that the 9th-century books were designed to serve, and the earliest sources are not themselves identical, either in their selection of chants or versions of the melodies they transmit So, one by-product of the restoration work has been a great deal of information about the earliest sources which is of immense value to those on whom the onus of producing practical editions does not rest

To many, plaınchant seems the musical embodıment of the eternal values of the Christian Church, and there is perhaps a temptation to regard it as an unchanging form But very few previously accepted views about the development of the repertory have escaped scrutıny, and a surprising number have been rejected or are at least hotly debated Much recent writing is evidence of a healthy scepticism and abundant imagination, and the issues debated have implications beyond the study of plainchant itself they concern the ways in which music is learned and performed from memory, how the structure of medieval compositions can be understood, and why musical notation was invented
As an example of recent changes in scholarly thinkıng we might take the fate of the traditional view that the liturgy of the Christian Church, and hence its music, has its roots in the Jewish synagogue This was an idea so simple and appealing that it inspired numerous attempts to find musical correspondences between Jewish and early Christian melodies for example, the resemblances between chants of the Jewish communities in the Yemen (published by Idelsohn) and Gregorian tones for singing psalms and lessons ${ }^{1}$ If the book of Psalms was the fundamental source of texts for singing in Christian worship, then the Christians would surely have borrowed the manner of singing as well. While musical correspondences have yet to be reinvestigated fully, the notion that Christian psalm singing was based on a Jewish model has been strongly attacked In complementary articles John Smith ${ }^{2}$ and James McKınnon ${ }^{3}$ have between them made the following crucial points.

(1) no such established synagogue services existed which could have been taken over by the primitive Church in the decades following Jesus's crucifixion, (2) there is no documentary evidence of regular psalm singing in synagogues during the first 500 years of the Christian era,

(3) although the recitation of the Hallel (Pss cxi11-cxv111) in the synagogue can be traced as far back as the second century $\mathrm{AD}$, it functions as a scripture lesson rather than as 'chant' in any sense commonly understood,

(4) the link between Jewish and Christian singing is rather at ceremonial meals in the home the Jewish Passover seder, and the Christian agape ('love-feast'), descendent of the Last Supper, itself a Passover meal

The singing of psalms in Christian liturgies is rightly associated very strongly with monastic communities who performed them in cycles as a religious exercise This 1s, however, a considerably later development commemoration of the Last Supper, the Mass, was eventually separated from the love-feast and its form developed over centuries to become that which we find reflected in the earliest music books of the Carolingian period But the stages of that develop- 
ment-in so far as they concern the chants sung at mass-are still very obscure. Work by Peter Jeffery ${ }^{5}$ and Joseph Dyer ${ }^{6}$ has been particularly revealing here. Jeffery's subject is a passage in the Liber pontificalis (a collection of early papal biographies) which has previously been understood to refer to the introduction of antiphonal psalmody as an introit chant in Rome by Pope Celestine 1 (422-32) He has shown that the innovation concerned not the introit (the adoption of which lay in the future) but responsonal psalmody interpolating the readings and most likely consisting of excerpts from rather than complete psalms

Of all the chants of the Proper of the Mass, the offertory is perhaps the most intriguing. Although a remark of St Augustine has been understood as referring to the chant's existence in Africa in the early 5 th century, Dyer has shown that this interpretation cannot be sustained, it may even refer to the introit in its 9 th-century notated form the offertory has elaborate melodies, with extended verses, so that outwardly it somewhat resembles responsorial forms such as the gradual and office responsory But it has traditionally been regarded as descended from antiphonal psalmody, in which psalm verses are sung antiphonally (alternatim) to a simple tone, with an antiphon (or refrain) between the verses Dyer has attacked this puzzle as well His thorough review of the evidence elicits no support at all for the idea of an earlier antiphonal method

Even when early references to this or that chant can be securely interpreted-and the articles just cited show how slippery these references can be-we can only infer by analogy what the musical form of the chant might have been, the level of elaboration, and the sort of formulas or tones that might have provided points of reference in its performance That is the state of affarrs up to the end of the ninth century, when the first fully notated books of chants for the Mass appear ${ }^{7}$ It is the century and a half up to that time which has provoked more recent writing than any other period The problems are (very roughly) these (1) The surviving early sources of the years around 900 are the result, at several generations' remove, of the special efforts made in the latter part of the eighth century by Pepin and Charlemagne to bring Christian worship, including its music, more into line with Roman practice In what state was the Roman chant they knew, and in what form was it established in Frankısh song-schools? Was some sort of notated exemplar used in its transmission from Italy? If not, when and by whom was the repertory first notated, and how was a notational system devised?

(2) Whatever the exact point when it was first written down, untıl then the chant repertory developed as an oral tradition, learned through constant listening and repetition How was it possible to master and perform this vast body of music for the liturgical year? If this was how the Frankish singers learned the Roman chant, how well did they learn it?

(3) The last question gains special point because of the existence of the famous 'Old Roman' manuscripts, dating from the 11 th century onwards, which are the sole early medieval sources of chant as sung in Rome itself ${ }^{8}$ They transmit a repertory quite different from the Frankush sources of $c 900$ and later What is their relationship (1) with the Roman chant that the Franks learned (2) with the chant in the manuscripts the Franks eventually produced?

There are three sorts of problem here questions about who did what, where and when, questrons about the role of oral transmission of chant and how it worked, and the matter of when and how notation developed

The questions about oral and notational transmission of chant are the most interesting ones What we know about the persons and events concerned with musical activity under Pepin and Charlemagne has been avallable in print for some time, ${ }^{9}$ and while more information may come to light, it seems unlikely that it will alter the picture drastically If we are able to explain the musical processes involved, it will be easy enough to decide when and where it took place, and who was responsible, but the reverse cannot be claimed

To solve musical problems one has to rely on musical sources, and after a protracted period of skirmishing with names and theories scholars have concentrated increasingly on the music itself The remarks that follow will be given point by ex 1 , the first section of the gradual Tenusti manum, transcribed from six different sources four Frankısh and two local Roman The six are

(1) Laon, Bibliothèque Municipale, 239 (gradual, Laon, early 10 th C), p 89 of the facsimile in Paleographie Musicale, $\mathrm{I} / \mathrm{x}$

(11) Verdun, Bibliothèque Municipale, 759 (noted missal, monastery of St Vanne, Verdun, 13th C), f $81 \mathrm{r}$

(iii) St Gall. Stıftsbibliothek, 359 (cantatorium, St Gall, late 9th C). p 89 of the facsimile in Paléographie Musicale, II/11

(iv) Graz, Universitatsbiblıothek, 807 (gradual, Klos- 
terneuburg. 12th C). f.84v. facsimile in Paleographie Musicale. I/xix

(v) Vatican City. Biblioteca Apostolica Vaticana, Vat.
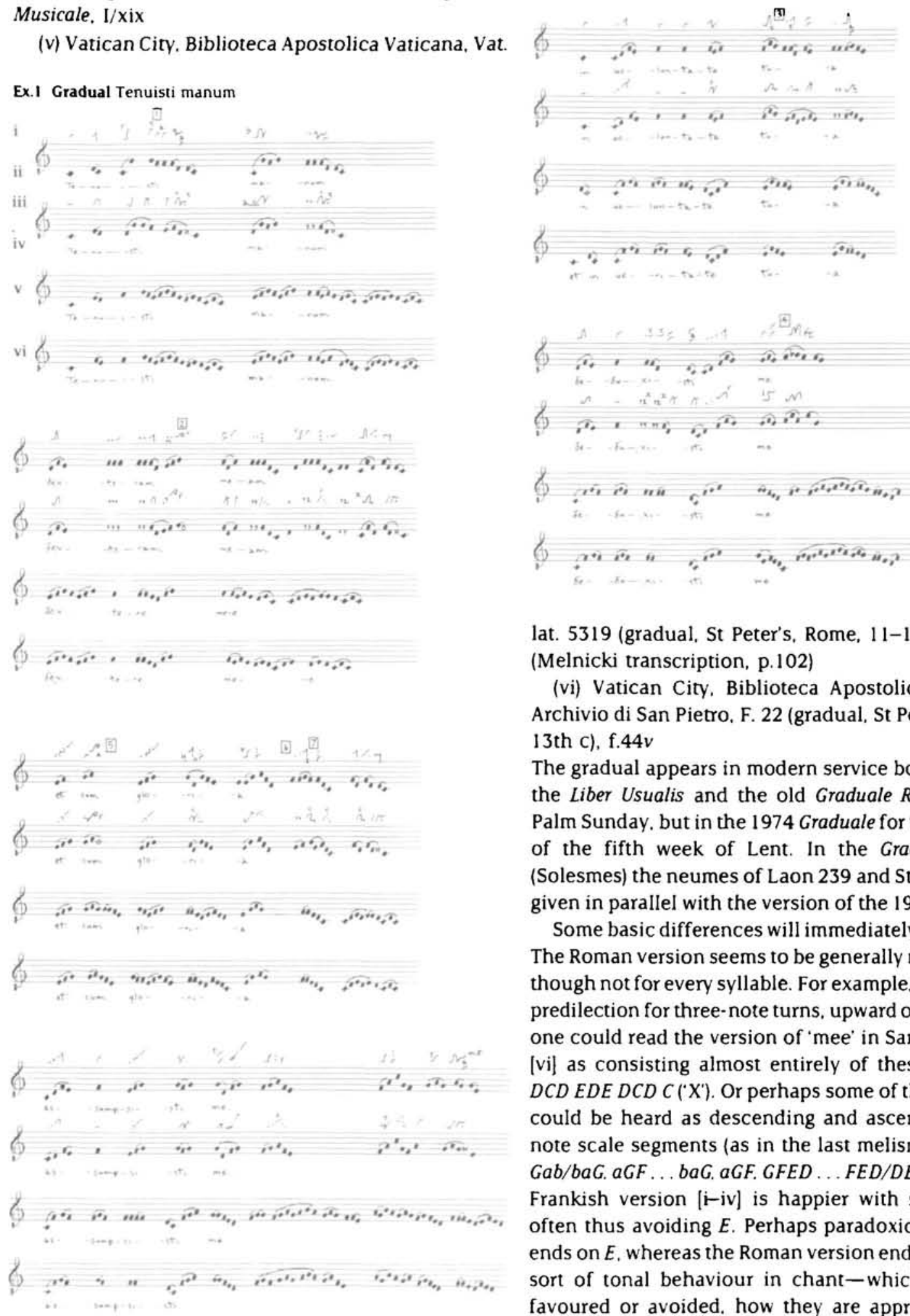

lat. 5319 (gradual, St Peter's, Rome, 11-12th c), f. $73 \mathrm{v}$ (Melnicki transcription, p.102)

(vi) Vatican City, Biblioteca Apostolica Vaticana. Archivio di San Pietro, F. 22 (gradual, St Peter's, Rome, 13th C), f. $44 v$

The gradual appears in modern service books such as the Liber Usualis and the old Graduale Romanum for Palm Sunday, but in the 1974 Graduale for the Saturday of the fifth week of Lent. In the Graduale Triplex (Solesmes) the neumes of Laon 239 and St Gall 359 are given in parallel with the version of the 1974 Graduale.

Some basic differences will immediately be noticed. The Roman version seems to be generally more ornate. though not for every syllable. For example, it displays a predilection for three-note turns, upward or downward: one could read the version of 'mee' in San Pietro F.22 [vi] as consisting almost entirely of these: FEF EDE $D C D E D E D C D C$ (' $\mathrm{X}$ '). Or perhaps some of the melismas could be heard as descending and ascending threenote scale segments (as in the last melisma (' $\left.Y^{\prime}\right)$ : $F G a$. Gab/baG. aGF ...baG aGF. GFED ...FED/DEF/FED). The Frankish version [i-iv] is happier with small leaps. often thus avoiding $E$. Perhaps paradoxically. it then ends on $E$, whereas the Roman version ends on $D$. (This sort of tonal behaviour in chant-which notes are favoured or avoided. how they are approached and 
quitted-has been the subject of a rather formidable computer-assisted statistical study by Finn Egeland Hansen. Being based on a complete transcription of one of the earliest Frankish manuscripts whose pitches we can read exactly, Montpellier H. 159 (Dijon. St Benigne), it referred to the local Roman manuscripts only in passing. ${ }^{10}$ ) Because the Frankish version is more sharply contoured than the Roman one, it is probably easier to learn note for note.

If we listen to these versions quite innocently. we should probably judge $F$ to be a key note or tonic of some sort; the phrases of both versions tend to rise up to it from a low start and fall away from it at the end of each phrase. In this respect both $E$ and $D$ are equally satisfactory as closing notes. Familiarity with other graduals, however, would make $E$ or $D$ seem more inevitable, for long acquaintance would have accustomed us to expect a particular final cadence. In certain circumstances $F$ is associated with a turn in the local Roman versions: twice at 'vo-lun-tate', twice at 'de$d u$-xisti' and twice more at 'as-sum-psisti'. Yet despite these differences-the less 'gapped' scale of the Roman version. its higher degree of surface ornament, its occasional preference for different cadence notesthere is undoubtedly a resemblance between the two. It is strongest for the word 'deduxisti'. If we allow ourselves to think of the Roman version as 'ornamen-

Ex.1 from Gradual Tenuisti manum
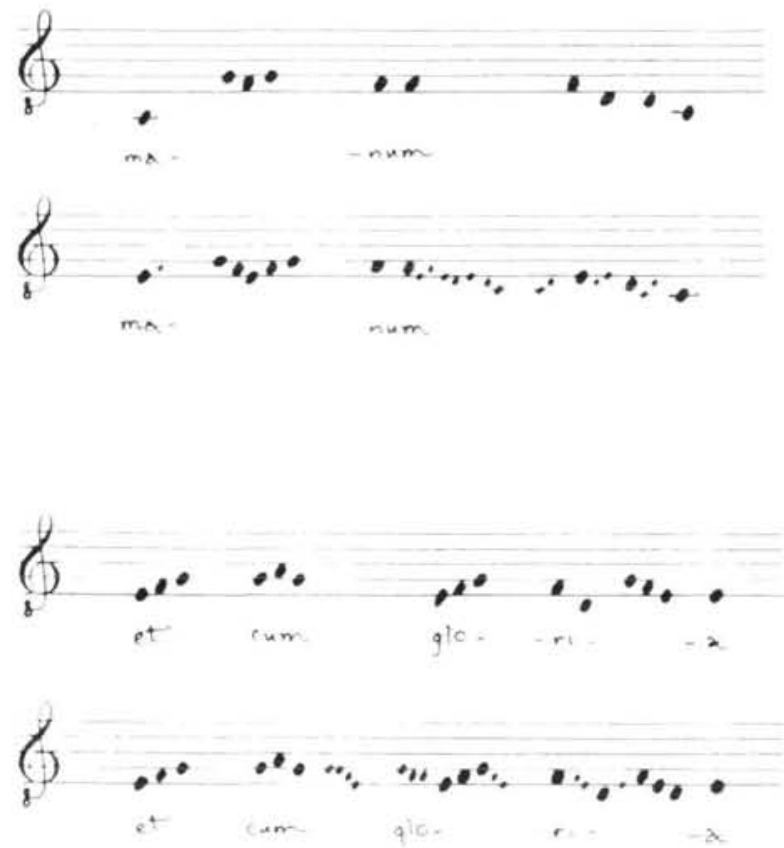

ted', we might perhaps imagine that what was ornamented was something like the Frankish version. as for example at 'manum' (ex.2a). or 'et cum gloria' (ex.2b).

However, this does not seem satisfactory: the notion of framework and ornament is too rigid and hierarchical. inappropriately applied to the fluid substance of which these chants consist. It is easier to agree that the melodies have something more basic in common: the sense of where text phrases begin and end. how this should be reflected in the music, and which individual words or groups of words should be heard as units. This is mostly done by establishing $F$ as a central note, rising to it in opening gestures, falling away from it in cadence melismas. So both versions agree that the first two words, 'Tenuisti' and 'manum', should be treated as separate units, moving towards $F$ but falling back to cadence on $C$ : that was somewhat unpredictable, so the agreement does not look like coincidence. They both agree that 'meam/mee' is the place for a longer cadential melisma; that et cum gloria' should emphasize $E$ and $G$ at the expense of $F$ : and so on. In sum, the two agree upon a mode of delivery for this particular chant text. And (though this cannot be demonstrated here) if one were to put other graduals beside this one, it would eventually become evident that this mode of delivery was felt to be the appropriate one for a whole group. for a particular point within the liturgy.

Looking at the chant in this way. one could agree with Helmut Hucke's oft-quoted linguistic analogy that the relation of the Frankish to the local Roman version is that of 'a faithful translation from a foreign musical language. " A rather literal translation, in fact. for Hucke has ingeniously shown instances where the local Roman version of a gradual deviates from normal practice with regard to musical grammar and syntax. and a hiatus appears in the Frankish version as well. The two 'languages' are similar enough to have almost identical rules, but the 'words' are pronounced differently. as between dialects. To agree with this analogy is to admit that the Franks were already accustomed to singing a chant repertory in their own tongue. as it were. to which the Roman one was now adapted

This assumes that the local Roman version is in some way prior to the Frankish one. a point on which all scholars are agreed. although. given the date of the earliest written sources 11 th century for the Roman. 9th century for the Frankish), this does not at first sight seem obvious. Firstl. the liturgl which the Roman 
melodies serve has archaic features which predate the modifications made for Frankısh use under Pepın and Charlemagne though this is not conclusive, it is evidence of remarkable conservatısm Secondly, there is very little trace of a modal systematization of the Roman melodies, something which the Frankısh repertory was already undergoing in Charlemagne's tume ${ }^{12}$ If the Franks adopted, or 'translated', music from Rome they also used it in a revised liturgy and organized it modally. ${ }^{13}$

It is nevertheless possible that the Roman versions we have are not in every detail what the Franks heard in the 8 th and 9 th centuries. That the Roman manuscripts often display quite wide divergences of melodic detail suggests that the constant oral recreation of chants during liturgical performance contınued through the period of copying, so that the manuscripts record different realizations of chants whose main mode of transmission was still oral, not written. This is evident not so much in Mass chants such as the gradual Tenuisti manum, as in Office chants, as Paul Cutter has demonstrated ${ }^{14}$ However, it is probably simplistic to imagine an absolute cleavage between oral and written transmission, and I find Edward Nowacki's suggestion attractive, that the local Roman sources were compiled by scribes using pre-existent copies as an alde-mémorre-'referring to them for text underlay and phrase structure, but then turning away and writing down whole phrases in the form already assimilated from years of exposure to the tradition' is

Nowackı has also shown how the Frankısh and Roman traditions came to diverge after the 'breakdown in liturgical liaison between the Roman and Frankish churches in the waning years of the Carolingian empire ${ }^{16} \mathrm{He}$ tackles the large number of instances where antiphon texts were assigned to two different melodic types in the two traditions (This is rather sımilar to attending a Sunday service in an unfamiliar church and discovering that a hymn is sung to a different, though equally well-known, tune from the one we are used to ) Here the analogy cannot be that of translation into a differing musical language or dialect One could assume that the Franks learned the standard melodies but not every instance of its employment, and made different choices But, Nowackı argues, the obvious pains that the Franks took to get things right, the extra musical aid they had developed in the shape of the modal system, and the greater length of time during which the Romans transmitted their repertory orally, make it much more likely that the changes occurred in Rome.

If oral transmission of the local Roman chant seems certain up until the 11 th century, and continues in part thereafter, what of the Frankısh manuscripts? Here again, there are characteristic disagreements between the sources which argue for a contınuing oral transmission of the repertory $A$ few are visible in ex. 1 . disagreements over $E$ and $F[1,3,6,7$ in ex 1$]$ or $b$ and $c$ [4], or the presence or absence of liquescents [2,5] As in the Roman manuscripts, extra passing notes and anticipations occasionally appear Once again, the different versions are most strikıng in offıce chants; they can be seen, for example, in the parallel versions of the Magnificat antiphons edited by Joann Udovich ${ }^{17}$ If we were to inspect the vast collection of parallel transcriptions compiled over the years at Solesmes, we should find numerous disagreements, some of which have reached the academic literature. ${ }^{18}$ For a substantial batch of mass introits, Hendrik van der Werf has recently published up to ten parallel versions, ${ }^{19}$ encompassing not just Frankish sources, but also Roman and even Milanese (Ambrosian) ones. ${ }^{20}$

One very noticeable difference between early Frankısh sources, which I have tried to reproduce in ex 1 , is of course the different types of neumes they employ That could be seen as a further argument in favour of oral transmission: wherever and whenever the decision was taken to make a copy of the church's music locally developed notation was employed Otherwise one would not expect to find such a great variety of calligraphy

I have referred to the two versions of the chant repertory as 'Frankısh' and 'local Roman', because the earliest manuscript examples are respectively Frankısh and local to Rome We are used to callıng the 'Frankısh' version 'Gregorian' The name 'Gregorian' was applied to books with chant texts as early as the 8th century, that is, before the repertory had been codified in neumes, so that we do not know exactly what version of the music was sung for those texts the term simply meant 'Roman' use, as established by Gregory the Great

The role of Gregory (d 604, long before any music manuscripts were written) is another contentious subject Documentary evidence of Gregory's liturgical activity is rather meagre. and of the ways in which it would have impinged upon music thinner still $A$ considerable amount of speculation and hypothesis surrounds it The first documented connection of his 
name with books of chant texts (it is generally agreed that would not have been notated) occurs in the Dialogus Ecclesiasticae Institutionis of Bishop Egbert of York (732-66). who twice referred to 'Gregory's ant1phoner' It is possible that he had in mind books he had actually seen in Rome, attributed to Gregory, when he had journeyed there just before his ordination ${ }^{21}$ The English were proud of the fact that Augustine. Apostle of the English, had been sent by Gregory himself to convert their land, and thus the attribution of their liturgical customs to Gregory was only natural The same belief could have taken root on the continent by several means, among them the influential presence of Egbert's pupil Alcuin at the Carolingian court Less than 40 years after Egbert's death, the first surviving books with chant texts were written with a heading. sometımes a full-blown prologue, attributıng their contents to Gregory ${ }^{22}$ We have all seen the charming pictures of a dove perched on Gregory's shoulder, supposedly singing plainchant to him alas, that idea is a twisting of the original legend, for the earliest lives of Gregory report that the dove was inspiring Gregory's commentary on Ezekıel ${ }^{27}$

Not all scholars are agreed that 'Gregorian' chant is a Frankısh rather than a Roman tradition. Bruno Stableın argued in a series of articles that the 'Gregorian' version was the result of a musical revision of the older Roman version (thus 'Old Roman') prepared in Rome itself under Pope Vitalian (657-72), possibly in emulation of the splendour of Byzantine liturgical practice ${ }^{24}$ Difficulties attaching to this explanation of the origin of the two versions have often been pointed out, perhaps most succinctly in the latest of Hucke's surveys of the evidence ${ }^{25}$ I too find it difficult to believe either (1) that the two versions in their surface detail, which is where they differ, can really be exactly like whatever was sung in Vitalian's time, or, more importantly, (2) that ecclesiastical or even political considerations could occasion, not a new liturgy (the adoption of a 'Byzantınızed' order of service) or even the composition of new items within the same liturgy, but some sort of musical tampering with extant melodies, or. in the case of the office antiphons, the exchanging of one well-known melody for another ${ }^{26}$ Pepin and Charlemagne did not tamper, they imported a complete liturgical use, music and all The prime consideration in such affairs has always been correctness and uniformity of worship, not musical aesthetics In the 12 th century, the $C$ istercians first revised their liturgy. then tried to find a suitable version of the chant repertory to serve it, and only then decided to carry out a musical revision as well in the 13th century, the papacy decided that its books and those of the Franciscans should be uniform Older Roman service books were banned, and no doubt most extant copies of the local Roman chant perished with other service books. In that both the Frankısh and the local Roman versions are derived distantly from chant in Gregory's time, they are both versions of Gregorian chant Other scholars have preferred to maintain the distinction between 'Gregorian' (the version sung at the papal court, and which the Franks received), and Old Roman (the chant sung in Roman churches)

To agree that the Franks learned a special papal version of the chant-either by going to Rome, as some of their singers did, or from Romans who came over the Alps to teach them-is to attribute to them remarkable powers of memory-indeed, the aural equivalent of a photographic memory It was argued that the differences between Frankısh manuscripts are best explained as the result of decisions taken at different tımes, in different churches, to make an authoritative copy of the local chant repertory Nevertheless, for Mass chants at least the differences are so small that it is not so difficult to believe that the Franks could memorize a great deal of the chant repertory in a very exact way If the resultant copies. written a century after Charlemagne's tıme, are so uniform, surely it follows that the Franks were capable of learning Roman chant with great accuracy of detail? It would also follow that the additional lapse of time before the Romans made copies of their music, as well as the translation into Frankish dialect, and perhaps some rationalization connected with modal system. atızatıon, were responsıble for the sorts of differences we see in ex 1 The chant the Romans actually sang in the 8th century can therefore only be percelved through two equally dark glasses near-contemporary Frankısh and much later Roman

Much depends on what we believe it possible for the human mind to remember exactly what is remembered. to form the basis of, in this case. oral re-creation of a musical corpus A group of stımulatıng studies by Leo Treitler has explored these and related matters, and greatly increased general awareness of the problems ${ }^{27}$ Drawing upon the evidence of other orally transmitted repertorres (such as Homeric poetry) and studies of rememberıng. Treitler has argued that a singer did not learn individual items note for note, 'as if he had swallowed a score' ${ }^{28}$ Rather he put into practice a 


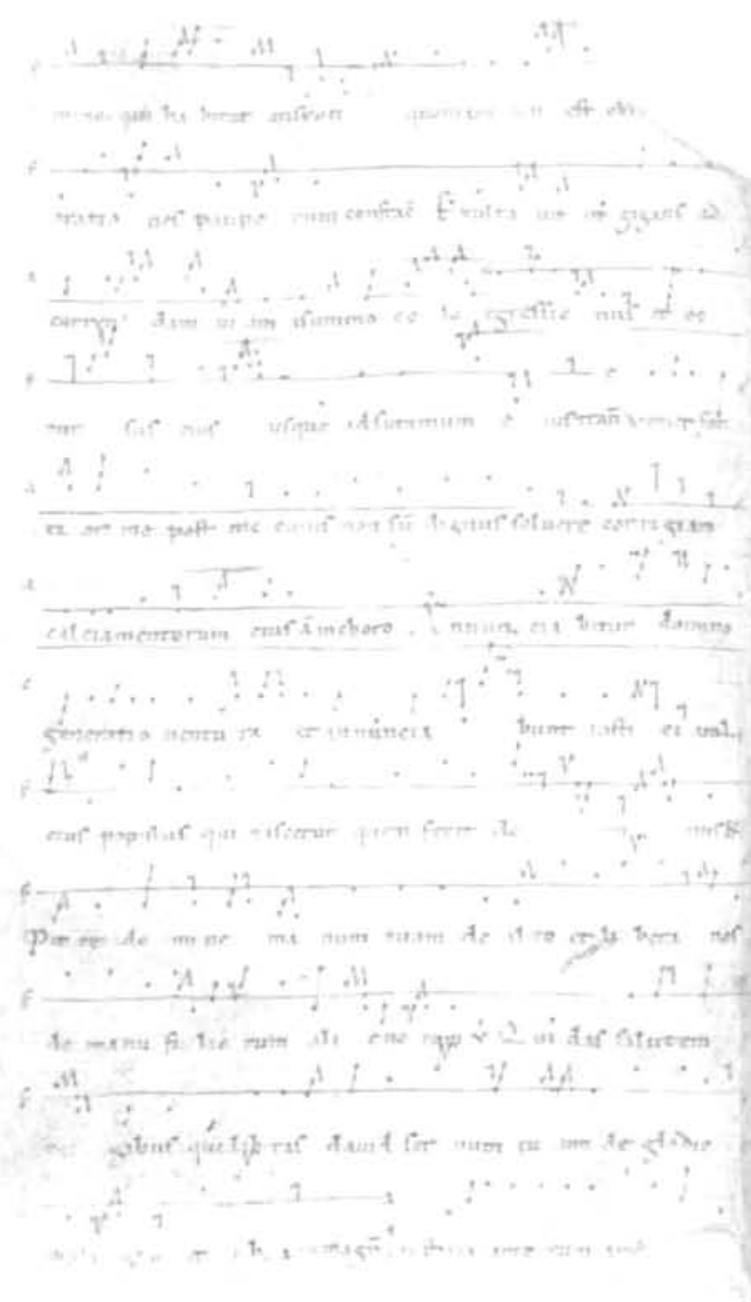

2 Ambrosian chant book, winter part 12th century (London. British Library. Add.34209. p.8). On line 2 is the Advent Communion Exultavit ut gigas.

musical technique, or strategy. developed for the appropriate delivery of not one. but a whole group of texts of a particular type and liturgical class: for example, the verse, of a tract, in mode 2 . with four text phrases-four categories affecting how he performed the chant. Where appropriate he would make the musical gestures of intonation and cadence, dwelling on recitation pitches, the whole within a tonal system where certain important pitches exercise complemen. tary attraction. such as the tenor (often repeated. towards which the phrases gravitate. $F$ in ex.1). and final. When the same method is used repeatedly on a

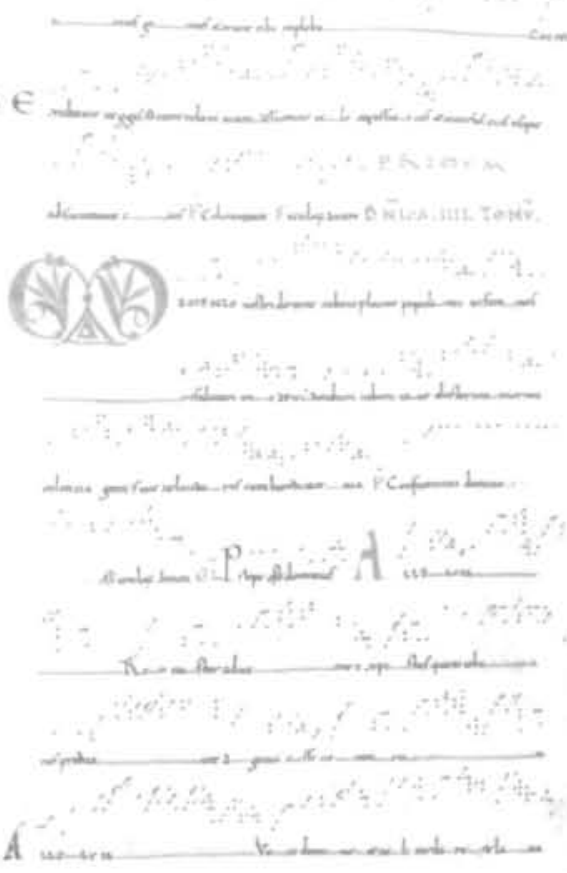

3 Graduale from Toulouse, I th century (London, British Library. Harley 4951, f.129). On line 2 is the same Communion in its 'Gregorian' version.

group of texts then the same strings of notes will often be used, formulas which have evolved as the most constant in a set of variable procedures. Whereas Apel had analyzed chants such as tracts as combinations of 'free' passages and clichès, it would be better to account for all parts of a chant as equally subject to the constraints of liturgical singing. The singer does not proceed at random until the moment comes to insert the next precomposed gobbet. Beginnings and endings become naturally more stereotyped. being more crucial to the articulation of the piece. Other parts of text have to be dealt with in more various ways. being in themselves so much more variable in content, but the singer must still work within a controlled system. In this situation composition is performance itself.

This implies that the Frankish singers did not learn every melody note for note. but instead mastered a formulaic system. They learned from the Romans how to articulate the text, where intonations, recitations and cadences should occur. the tonality of chants 
(though sometımes their tonal sense, and the development of the eight-mode system, caused changes) and general concepts of the degree of floridness in the music, together with a number of characteristıc turns of phrase And that, in a general way, would account for the sorts of resemblances and differences between the two main versions of Tenuisti manum

Treitler's ideas have seemed most convincing when exemplified through tracts, where the techniques of composition-through-performance are clearly in evidence At the same time, it should be recollected that large parts of the chant repertory-for example, introits, offertories and communions-do not provide such unambiguous evidence of the formulaic system Furthermore, while the tract was sung by a solorst, other chants were not, including parts of some formulaic chants, graduals for example. More extensive discussion of the way in which groups of singers developed the competence to sing together without error would be useful Presumably the chorces open to the solo singer are denied to the choral group is this tantamount to saying that the melodies were more or less rigidly fixed, and must be learned note-for-note? Among some highly penetrating recent writing about introits, ${ }^{29}$ this particular consideration has not been discussed Hucke believes that 'the multitude of "original" melodies for the schola' (as opposed to "'typical" melodies for the cantor') is a product of the notator's fancy when the melodies were originally written down, the notator would have worked under 'lesser constraints' when dealing with introits than when trying to follow the 'more complex system of rules and performance procedures' of the cantorial art 'For the melodies of the schola he would have given examples of how they could artfully be sung ' Yet the schola must have agreed on how it was to sing its melodies so artfully, and I am readier than Hucke to believe that it is with the schola's melodies, not those of the cantor, that 'we are probably closer to what was sung' 30

This in turn implies a dispanity between what was actually sung and what is written in books it has often been suggested that the earliest books are not performance scores, but reference books for consultation in the song-school For the cantor's solo items, therefore, they could be said to represent one way, perhaps an ideal way, but not the only way, of performing the chant The copy is like a frozen performance One comes back again to the problem that large numbers of chants, though undoubtedly com- posed according to the principles Treitler has outlined, had to be taught in the same song-school to a choir This demands a degree of fixity in the melodies no less permanent than if they were encoded in neumes In such circumstances I find it difficult to believe that the cantor's book and the chorr's performance were at odds

An interesting development in Treitler's ideas has been charted in his most recent articles, where the nature and role of musical notation is investigated ${ }^{31}$ He argues that if it was not a string of pitches that was learned, but a formulaic system for delivering the text, then the essentials of early notation lay not in representing individual pitches but in aiding recognition of crucial points in the text and indicating appropriate melodic gestures This implies a sort of musical punctuation so we should consider the possibility that early neumes developed as and from punctuation signs Early neumes eventually served two purposes 'the coordination of melodic inflections with syllables of text and the directions of melodic movement within the inflections' for each syllable (or sub-phrase within a longer melisma) Pitch representation was never their aim the singer would have known what was appropriate because of his 'mastery of the modes and melodic types' ${ }^{32}$ That this mastery was indeed great is shown by the relatively high degree of agreement between sources when pitch notation was eventually used from the 11 th century onwards (compare the pitches of the Verdun (11) and Klosterneuburg (iv) sources in ex 1) If new sources in the new notation were prepared independently, they display a remarkable uniformity or should we again ımagine that exemplars in pitch notation were widely circulated and used as guides?

In elaborating this idea, Treitler strongly attacks the oft-repeated explanation that neumes developed from the accent signs of classical prosody It may nevertheless be pointed out that grammatıcal studies were part of the Carolingian educational programme, and grammatical treatıses including information about prosodic accents were copied, even composed by Carolıngian scholars A knowledge of classical accent signs could easily have contributed to the making of musical notation, especially in circumstances of 'delıberate experımentation' and 'rapıd development' which Treitler is willing to countenance ${ }^{33}$

Another long-standing idea, that early neumes are 'cheironomic' (representing the cantor's hand gestures as he leads his choir), has also been challenged, by 
Hucke ${ }^{34}$ Insofar as cheironomic techniques in the proper sense indicated pitches and intervals-precisely what early Western neumes did not do-Hucke is undoubtedly correct (It would be interesting to know If any reader has ever been guided through a performance of a piece of well-known chant without a written copy, enturely by a director using, say, St Gall neumes as a model for his hand gestures, that is, reversing the assumed progression from hand gestures to notational signs)

With their wealth of rhythmic detall and the variety of shapes avallable to suggest nuances of delivery for the same melodic contour, the neumes I copied in ex 1 are evidently extremely sophisticated The literature about their interpretation is by now very large ${ }^{35}$ They are clearly the result of local efforts immense, as well as ingenious, efforts, and by no means first attempts Earlier notated examples are not so rich in detal, the earliest are not usually dated before the 9 th century ${ }^{36}$ Notation seems first to have been used only for isolated pieces, not complete books, and not usually for the chants of schola or cantor Most of the regional types of neumes found in profusion in the 10th century are also to be found already in the 9 th If one type of notation could be shown to antedate all others, one might yet argue the case for a written tradition for the major part of the chant repertory going back to the first part of the 9 th century, but the situation here too is unclear Stablein believed in the sequence of derivation from the Paleofrankish notation through Breton to others, startıng around or shortly after $800^{37}$ While theoretically possible, this remains undocumented, and the question persists as to whether the whole Mass repertory, as we find it in Chartres 47, St Gall 359 and Laon 239 (see $\mathrm{fn} 7$ ) was ever copied in Paleofrankısh notatıon

After a period when general opinion seemed to be moving away from the notion of a single chant archetype codified around 800, Kenneth Levy has strongly reaffirmed the possibility ${ }^{38}$ Levy discusses seven 'indices' of an early codification of the chant repertory Some of these are positive rather than sceptical reassessments of data such as the appearance of the word 'nota' (written signs or simply unwritten music?) in Charlemagne's Admonitio generalss (789) Other indices are a question of probability that early manuscripts have been lost, that different notational styles developed from a single early prototype (Levy does not describe what it might have looked like) Another piece of documentary evidence is Aurelian of
Réome's Musica disciplina (c 850), which seems to refer to notational signs in a way that presupposes the existence of complete notated antiphoners Levy's previous work on old Italian chant repertories is well known, and it plays a part in his arguments here It is generally recognized that the Franks gave a new chant repertory to the Duchy of Benevento in Southern Italy, after seizing political control there, some time between 787 and 838 Traces of the older Beneventan chant survive patchily Levy believes the new music came in a written exemplar, because the neumatic details of the Beneventan readings agree with those of northern Europe' He illustrates this by displaying versions of the offertory Factus est repente, in some of its very rare 'northern' and 'southern' versions The agreement is so consistent that Levy can argue for written transmission, which for this particular item he reckons must have taken place around 800 (it was generally displaced by Confirma hoc)

This is in effect an extreme example of the similanties between the Laon (1) and St Gall (111) versions in ex 1. with a special historical twist and wide geographical separation of the sources involved And it begs the question whether singers could remember not only notes but also their phrasing (reflected in written note groupings) and the peculiarities of delivery represented by the quilisma, oriscus etc, so well that independently prepared copies would agree Levy believes a neumed archetype must underpin the process One awaits with interest an exposition of his ideas on the FrankishRoman question how well does his supposed archetype reflect Roman musical practice $c 800^{2}$

The storm of new ideas and material shows no sign of abating, and my summary reflects no more than a present and temporary understanding of the matter Sailıng these particular seas is indeed exhilarating at present, more hands on deck would be welcome Although there are contrary opinions about how the ship should be handled, and differing expectations about what will be discovered when land is finally sighted, the voyage of exploration is still making considerable way

David Hiley is currently at the University of Regensberg and is a regular contributor and reviewer for Early Music in the field of plainchant and early polyphony

\footnotetext{
'There is a convenient summary of some of the older writing in W Apel. Gregorian Chant (Bloomington, Ind 1958. 3/1966 pp 34-8 The reader will wish to compare the information in The New Grove Dictionary with articies cited here written after $c 1975$
} 
${ }^{2} J$ A Smith, 'The Ancient Synagogue, the Early Church and Singing', $M L$, lxv (1984), pp Iff

${ }_{3}^{3} \mathrm{~J} \mathrm{~W}$ McKinnon, 'On the Question of Psalmody in the Ancient Synagogue'. Early Music History. v1 (Cambridge. 1986), pp 159-191

${ }^{4}$ Books on this subject by two liturgical historians have appeared recently $P$ F Bradshaw, Daily Prayer in the Early Church. Alcuin Club Collections, 63 (London, 1981), and R Taft. The Liturgy of the Hours in East and West (Collegeville, Minn, 1986)

${ }^{5} \mathrm{P}$ Jeffery. The Introduction of Psalmody into the Roman Mass by Pope Celestine I (422-432)'. Archiv fur Liturgiewissenschaft, xxvi (1984). pp $147 \mathrm{ff}$

${ }^{6} \mathrm{~J}$ Dyer, Augustine and the Hymn ante oblationem the earliest offertory chants'. Revue des Etudes Augusumennes, xxvı (1981). pp 85ff, and 'The Offertory Chant of the Roman Liturgy and its Musical Form', Studi Musicall, xı (1982), pp 3ff

${ }^{7}$ The three earliest are Chartres, Biblıotheque Municipale, 47 (destroyed in 1944, facsimile in Paléographie Musicale, l/xi). from Brittany, copied in the closing years of the 9th century. St Gall. Stiftsbiblıothek, 359 (Paléographie Musicale, Il/11), from St Gall, same date, and Laon, Biblıtheque Muncipale, 239 (Paleographie Musicale, $\mathrm{I} / \mathrm{x}$ ), from Laon, early 10th century Before that only fragments have survived, or copies only of the texts of chants, which were probably for the priest's use

${ }^{8}$ There are three graduals and two antıphoners For the texts of the graduals see P F Cutter, ed. Musical Sources of the Old-Roman Mass, Musicological Studies and Documents, xxxv1 (Rome, 1979), see also the corrections by $\mathrm{T}$ Connolly given in Early Music History, 11 (Cambridge, 1982). pp 367-9 A transcription by M Landwehr. Melnıckı of one of the graduals (Vatican Library. Vat lat 5319). though with the pieces not in manuscript order, was published as Die Gesange des altromischen Graduale, Monumenta Monodica Medn Aevı, " (Kassel, 1970), with an introduction by B Stableın A facsimile of another gradual, with an index of all three, has just been published, ed M Lutolf, Das Craduale von Santa Cecilia in Trastevere (107l) (Cod Bodmer 74) (Cologny-Geneva, 1987)

${ }^{9}$ Between them, the following articles contain most of the important citations of the older literature $G$ Morin, Les ventables ongines du chant gregorien (Maredsous, 1890, orig pubd as a series of articles in Revue Benedictine, v11, 1890). R van Doren, Étude sur Iinfluence musicale de l'Abbaye de Saint-Gall (VIle au Xle siècle). (Louvain, 1925), among more recent non-musicological writıngs $T$ Klauser, 'Die liturgischen Austauschbeziehungen zwischen der romischen und der frankısch-deutschen Kirche vom achten bis zum elften Jahrhundert', Historisches Jahrbuch der Gorres-Gesellschaft, ! 111 (1933). pp 169ff, C Vogel, 'Les echanges liturgiques entre Rome et les Pays Francs jusqu'a l'epoque de Charlemagne', Le Chiese net Regnt dell Europa Occidentale e t Loro Rappont con Roma sino all 800. (Spoleto. 1960). pp 185-295 Some are reproduced in Stablein s contribution to the edition of Vat lat 5319. cited in the previous note But see also especially $\mathrm{H}$ Hucke, 'Die Einfuhrung des Gregorianischen Gesanges im Frankenreich', Romische Quartalschrift fur chnsthche Altertumskunde unde Kirchengeschichte $\mathrm{xl} \times$ (1954). pp 172ff pp $172 \mathrm{ff}$

${ }^{10} \mathrm{~F}$ E Hansen, H/59 Montpeller (Copenhagen, 1974), tdem. The Grammar of Gregonan Tonality (Copenhagen, 1979)

${ }^{13} \mathrm{H}$ Hucke. 'Gregorianischer Gesang in altromischer und frankıs. cher Uberlieferung', Archiv fur Musikwissenschaft, xn (1955). pp 74ff. here $\mathrm{p} 87$

${ }^{12}$ Again, it was Hucke who gave this important demonstration. first at the Berlin meeung of the International Musicological Society and then in 'Karolıngısche Renasssance und Gregorianıscher Gesang'. Die Musikforschung, xxvi11 (1975) pp $4 \mathrm{ff}$

${ }^{13}$ On the other hand. Dyer has shown that, contrary to earlier opinion, the chant texts in the Frankısh and Roman manuscripts are not based on different versions (of differing age) of the psalter $J$ Dyer. 'Latın Psalters, Old Roman and Gregorian Chants', Kirchenmusikalsches Jahrbuch, Irvil (1984), pp IIff
14 $\mathrm{P} F$ Cutter. 'The Old-Roman Chant Tradition oral or written" JAMS, $x \times$ (1967), pp $167 \mathrm{ff}$, idem, Oral Transmission of the OldRoman Responsories?', MQ. Ixı1 (1976). pp 182ff

${ }^{15} \mathrm{E}$ Nowacki. Text Declamation as a Determinant of Melodic Form in the Old Roman Eighth-Mode Tracts', Early Music History, vi (Cambridge, 1986), pp 193-226, here p 198 Nowackı's article is the most thoroughgoing demonstration of how the characteristic music of a particular class of chants is moulded for apt delivery of individual texts

${ }^{16} \mathrm{E}$ Nowackı. 'The Gregorian Office Antuphons and the Comparatıve Method', Joumal of Musicology, iv (1985). pp 243-275, here p 264

17 Udovich. 'The Magnificat Anuphons for the Ferial Office" Journal of the Plainsong \& Mediaeval Music Society. 111 (1980), pp 1 ff

${ }^{18}$ See in particular the sample edition of the proper chants of the Mass for the First Sunday in Advent in Les relanons genealogiques des manuscrits Le Graduel Romain 4/11 (Solesmes. 1962). pp 65-89 The Solesmes team made a statistical assessment of the similarity or disparity between over 200 manuscripts with Mass chants, in order to choose the sources for a new critical edition The project was described by the late J Froger. 'The Critical Edition of the Roman Gradual by the Monks of Solesmes', Joumal of the Plainsong \& Mediaeval Music Society. 1 (1978), pp 8 Iff On p 205 of the article cited in fn I. Mary Berry gave a reproduction, much reduced in size, of a page from the comparauve tables used to prepare the new edition One concern of the monks was to match the most ancient sources notated in neumes with later sources on lines. in order to help decide on the pitches of chants The two pairs of manuscripts used in ex 1, Laon and Verdun, St Gall and Klosterneuburg, are among those chosen by this method by Solesmes $J$ Clarre has published a substantial study of a group of office antiphons, including parallel transcriptions from a variety of sources 'Les Repertoires Liturgiques Latıns Avant l'Octoechos, 1 l'Office Ferial Romano-Franc'. Etudes Grégonennes, xv (1975). pp 1-192

${ }^{19} \mathrm{H}$ van der Werf, The Emergence of Gregonan Chant. 1 A Study of Modes and Melodies (Rochester, NY, 1983)

${ }^{20}$ In a paper read at the 1985 annual meeting of the American Musicological Society in Vancouver. David Hughes presented and commented upon a large number of typical examples of variance in Mass chants between Frankish sources, and opıned that these were best understood as the product of oral transmission, albeit one extremely consistent down to small details Hughes's findings have Just been published in JAMS. xl (1987). pp 377-404

${ }^{21}$ Egbert's text is avallable in $\mathrm{J}-\mathrm{P}$ Migne, Patrologiae latino, Ixxix, pp 420-24

${ }^{22}$ For the headings and prologues see R - J Hesbert, Antiphonale Missarum Sextuplex (Rome, 1935), and B Stablein. "'Gregorius Praesul", der Prolog zum romischen Antıphonale'. Musik und Verlag Karl Votterle zum 65 Geburtstog (Kassel, 1968), pp $537 \mathrm{ff}$ Hucke was the first scholar to re-open the question of the two versions of the chant repertory Die Entstehung der Uberlieferung von einer musikalıschen Tatıgkeıt Gregors des Grossen', Die Musikforschung. vi11 (1955), pp 259ff The English were ready to point to Gregory's authority when they felt their chant to be threatened, as at Glastonbury after the Norman Conquest of England The bizarre theory that the Norman abbot. Thurstan, wanted to impose Old Roman chant on the Glastonbury monks invented by J S van Waesberghe, is certainly erroneous see D Hiley, 'Thurstan of Caen and Plainchant at Glastonbury musicological reflections on the Norman Conquest'. Proceedings of the Bntish Academy. Ixxu1 (1986). pp $161-194$

2'See B Colgrave The Earhest Life of Gregory the Great (Kansas 1968 Cambridge 2/1985), pp 120-23 For llustrations see B Stableın. 'Gregor l' Die Musth in Ceschichte und Gegenwart, v (1966), and the same author's article cited in the previous note See also $L$ Trettler who noticed the change from Ezekiel to musical composition 'Homer and Gregory the transmission of epic poetry and plainchant'. 
MQ. $(x$ (1974). pp 333-73

"The fullest statement of Stablein's views appears as the introduction to Melnickis transcription of the local Roman gradual. cited in note 8 above. His suspicion of Byzantine influence was influenced by the arguments in E. Jammers study. Musik in Byzanz im papstlichen Rom und im Frankenreich der Choral als Musik der Textaussprache (Heidelberg. 1962). Jammers suggests that the Romans wanted to make the music more suitable for performance with an ison vocal drone. a technique unfortunately not documented until some eight centuries later. His ideas are the subject of trenchant criticism by Nowacki in 'Gregorian Office Antiphons'. pp 260 f

"'H. Hucke. 'Toward a New Historical View of Gregonan Chant'. JAMS, xxxili (1980), pp. 437-67

26 Jod, p.441. fn.19; and Nowacki. 'Gregorian Office Antiphons'. p. 262 .

"See L. Treitler. "Centonate" Chant: Übles Flickwerk or E pluribus unus?. JA.MS, xxviii (1975). pp.lff: and idem, 'Oral. Written. and Literate Process in the Transmission of Medieval Music'. Speculum, Ivi (1981), pp.471ff

${ }^{28}$ Treitler. 'Homer and Gregory: p. 344

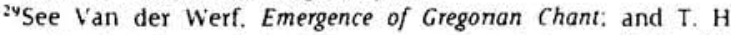
Connolly. Introits and Archetypes: some archaisms of the Old Roman Chant', JAMS. $x \times v$ (1972), pp. $157 \mathrm{ff}$

"See p.454 of H. Hucke. Toward a Nen Historical View of Gregorian Chant'. JAMS. xxxiii (1980). pp.437ff. This is not to challenge the conclusions that Hucke draws later in the article from a revealing comparison of Frankish. Roman and Milanese versions of an introit. His remarks are based on part of his contribution to a group of papers on transmission and form in oral traditions: Der Übergang von mündlicher zu schriftlicher Musiküberlieferung im Mittelalter'. Intemational Mustcological Society. Berkelev 1977. ed. D. Heartz and B Wade (Kassel. 1981), pp.180ff. But Hucke's revelation that the chord part of office antiphons could be as little as a short final phrase-this is clearly indicated in manuscript Lucca 601. (Paleographie Musicale, IX)-suggests a solution to the question for these pieces at least.

"See Treitler, 'Oral, Written and Literate Process': ıdem. 'The Early History of Music Writing in the West', JAMS, Axxv (1982). pp.237279: and $t d e m$. Reading and Singing: on the genesis of occidental music-writing'. Early Music History. iv (Cambridge. 1984). pp. $135-208$

"Treitler. 'The Early History'; p.245

${ }^{3}$ 'Treitler. 'Reading and Singing', p. 197. Treitler was hammering down the lid of a coffin already more or less closed: Stablein's last major work. Schriftbild der einstimmigen Musik. Musikgeschichte in Bildern (Leipzig. 1975) is noticeably silent about accents; S. Corbin. in her posthumous Die Neumen (Cologne, 1977) "as evidently unconvinced and left the matter open. though her likewise posthumous Niew Grove arucle 'Neumatic notations' unexpectedly and almost as an afterthought came down in favour of accent (The New Grove Dictionary of Music and Musicians, London. 1980. xiii. p. 129). In my part of the article Notation I was sceptical about accents. and too generous to the notion of a link with cantor's gestures. What may perhaps be called the 'Solesmes view' has been that a mixture of signs. all associated in some $w$ ay with written texts. were adopted and adapted for the new purpose. The sole origin. the controlling idea. which presided over the initial formation. still rudimentary. of all the notations. consists in the transference for the melod, itself of the accentuation and punctuation signs of the sung text.' IG .II Sunol. Introducnon a la Paleographie Musicale Gregonenne. Solesmes, 1935. p. 28)

${ }^{3} \mathrm{H}$. Hucke. Die Cheironomie und die Entstehung der Neumenschriftk: Die .Musikforschung. xxxii (1979). pp. Iff

"The painstaking studies of Eugene Cardine and his pupils have given much food for thought. To the literature alreadi cit in notes 15 and 16 (pp. 215f) of M. Berr. Gregorian chant the restoration of the chant and seventy-five vears of recording. E.M. vil (1979). pp. 197ff the following may be added E. Cardine's book is now atailable in an English translation b) R. M Fowels Gregonan Semiology (Solesmes, 1982). A rapid survey in English of the studies completed by Cardine's students is given by $\mathrm{N}$. Albarosa. The Pontificio Istituto di Musica Sacra in Rome and the Semiological School of Dom Eugene Cardine:. Joumal of the Plainsong \& Mediaeval Music Society. vi (1983). pp.26ff. A new forum for this tvpe of research is the twice-yearly Beitrage zur Gregonanik (Regensburg): three volumes have so far appeared.

${ }^{16} \mathrm{~V}$ arious listings have been attempted: my own draws in many instances on those given with facsimile and discussion in Jammers' writings: see Notation', The New Grove, xiii. p.346. Meanwhile another list had appeared, in Corbin. Die Neumen, p. 3.30. (The fact that her 12 and my 21 have only 7 in common shows how uncertain knowledge in this area still is.)

"Stablein. Schriftbild, p. 27

${ }^{31} \mathrm{~K}$. Levy: 'Charlemagne's Archetype of Gregorian Chant'. JAMS, xl (1987). pp.1-30

\section{EARLY MUSIC}

\author{
Editorial: 01-4939376 \\ Advertising: 01-352 6400 \\ Subscriptions: 086556767
}

\section{Cambridge Music Shop}

At the Cambridge Music Shop our aim is to provide the best possible service to everyone interested in classical music.

We sell early music of all kinds, for most instruments and for voices: music for practice and for progress, for performance and pleasure. Our stock ranges from the complete Musica Britannica to beginners' tutors. Early music is our speciality and we post anything anywhere. Send us your next order and we will do our best for you.

All Saints' Passage Cambridge CB2 3LT Telephone (0223) 351786 